Journal of Engineering and Applied Sciences 7 (1): 72-78, 2012

ISSN: 1816-949X

(C) Medwell Journals, 2012

\title{
Feasibility Study of Off-grid Hybrid Energy Systems for Applications in Ondo State Nigeria
}

\author{
Muyiwa S. Adaramola \\ Department of Energy and Process Engineering, \\ Norwegian University of Science and Technology, Trondheim, Norway
}

\begin{abstract}
The feasibility study of using hybrid energy systems for electricity generation in rural communities in Ondo state in the South-West of Nigeria is investigated in this study. Renewable resources (wind and solar) data in Akure which is the capital of the state is used as case study. Akure is located on the latitude of $7.25^{\circ} \mathrm{N}$ and longitude $5.20^{\circ} \mathrm{E}$. The effect of diesel price, changes in wind speed and daily global solar radiation on optimal hybrid energy system and the cost of a unit of electricity were studied. Hybrid Optimization Model for Electric Renewable software has been employed to carry out the present study. It is found that wind-PV-diesel hybrid system is feasible as stand-alone electricity generating system in Ondo state. The optimal simulation results indicate that the levelised cost of energy varies between $\$ 0.578$ and $\$ 0.682 \mathrm{kWh}^{-1}$ depends on the system configuration and diesel price. These costs are significantly lower than the cost of using diesel generator only (without battery) which varies between $\$ 0.913$ and $\$ 1.319 \mathrm{kWh}^{-1}$.
\end{abstract}

Key words: Wind turbine, diesel generator, PV, hybrid system, Akure, electricity, Norway

\section{INTRODUCTION}

Considering the huge energy resources available in Nigeria, it is surprising that electricity generation and distribution crisis have been the main obstacle to the economic development of the nation. The average electricity consumption per capital as at 2008 in Nigeria is $126 \mathrm{kWh}$ year ${ }^{-1}$ which is $<2 \mathrm{kWh} \mathrm{day}^{-1}$ for a household of five people. This per capital electricity consumption is very low and significantly lower than that of South Africa and Egypt which as 2008 are 4759 and $1425 \mathrm{kWh} \mathrm{year}^{-1}$, respectively. This low electricity consumption in Nigeria is primarily due to irregular and inadequate electricity generation and production which leads to less than half of the entire Nigerian population to have access to electricity and only about $10 \%$ of rural population of the country have access to electricity (Adaramola and Oyewola, 2011).

This scenario can be improved by using the solar and wind energy resources to supplement electricity generation in Nigeria. However, due to intermittent nature of these resources, they may not be suitable and reliable as stand-alone energy conversion systems. During power outage in Nigeria and in most rural areas, diesel generator is commonly used. However, old diesel generator can be noisy, produce greenhouse gases and has high operating and maintenance cost (Al-Badi, 2011). Also, accessibility to diesel oil may be difficult, especially in the rural areas and during fuel scarcity which is a common occurrence in
Nigeria. This can lead to increases in diesel price and hence high operating cost of the diesel generator. Therefore, integration of both renewable energy conversion systems with diesel generator and storage facility could be a reliable energy system in most rural areas in Nigeria.

The present study examines the feasibility of using hybrid energy system for electricity generation in rural areas in Akure, Ondo state. The effects of changes in wind speed and global solar radiation on the optimal hybrid energy system are examined. These changes will make the results of this study suitable for identifying hybrid energy system for almost all parts of state and other locations in surrounding states that have similar wind speed regime and global solar radiation data to Akure.

\section{MATERIALS AND METHODS}

Electrical load: The electrical load used in this study is based on the average electricity consumption per household in Nigeria as reported in literatures. Based on survey of ten households in Ilorin in central region of Nigeria, Ajao et al. (2011) reported an average electricity of $400 \mathrm{kWh} \mathrm{month}^{-1}$ (or $13.3 \mathrm{kWh} \mathrm{day}^{-1}$ ) per household. Adeoti et al. (2001) found that for rural area in SouthWest Nigeria, average electricity consumption per household is about $2.3 \mathrm{kWh}$ day $^{-1}$. In this study, electrical load of $25 \mathrm{kWh}_{\text {day }}{ }^{-1}$ with daily peak load of 
$3 \mathrm{kWh}$ is simulated. Based on the above studies, this load can serve two households in semi-urban area or about 10 households in small remote community. In addition, the $25 \mathrm{kWh}$ day $^{-1}$ load can be applicable to telecommunication installation (Khan and Iqbal, 2005), small business and community centres in rural areas. For this load profile, hourly and daily variations are taken as 25 and 15 , respectively.

Renewable resources: The performance of a hybrid energy system is depends on the renewable resources (wind speed and solar radiation data) which is a site-specific. Therefore, accurate information about wind speed and global solar radiation for the location of interest are essential. The renewable resources (solar and wind) data used in study are for Akure which is situated in the South-West Nigeria. This site is located on latitude $7.25^{\circ} \mathrm{N}$ and longitude $5.2^{\circ} \mathrm{E}$ and it is $384 \mathrm{~m}$ above sea level. In order for the analysis presented in this study to be useful in other locations in Ondo state Nigeria, range of values of wind speed and global solar radiation are used for sensitivity analysis.

Wind resources: The wind speed data used in this study were obtained from the Nigerian Meteorological Agency (NIMET), Oshodi, Lagos. The wind speed data were captured at $10 \mathrm{~m}$ height by a cup-generator anemometer. The monthly mean wind speed in Akure based on 28 years (1980-2007) wind speed data is shown in Fig. 1. Figure 1 shows that the monthly mean wind speed vary between $2.76 \mathrm{~m} \mathrm{sec}^{-1}$ in the month of November and $3.94 \mathrm{~m} \mathrm{sec}^{-1}$ in the month of March. The annual mean wind speed is determined as $3.26 \mathrm{~m} \mathrm{sec}^{-1}$ with correspond power density of $21.22 \mathrm{~W} \mathrm{~m}^{-2}$ (assumed that air density is $1.225 \mathrm{~kg} \mathrm{~m}^{-3}$ ).

In addition, it can be observed that there is noticeable variation in monthly average wind speed and hence, the monthly energy output from wind energy conversion systems would not be the same. The autocorrelation factor (randomness in wind speed) is found to be 0.83 . The diurnal pattern strength (wind speed variation over a day) is 0.08 and the hours of peak wind speed is 15 . For sensitivity analysis, eight different annual values of wind speed are used and these values are; 2.00 , $2.50,3.00,3.26,3.50,4.00,4.50$ and $5.00 \mathrm{~m} \mathrm{sec}^{-1}$.

Solar radiation data: The average daily global solar radiation on horizontal surfaces used in this study is obtained from the archives of National Aeronautics and Space Administration renewable energy resource website (NASA) for a 22 years period (1983-2005). The monthly daily averaged global solar radiation is shown in Fig. 2.

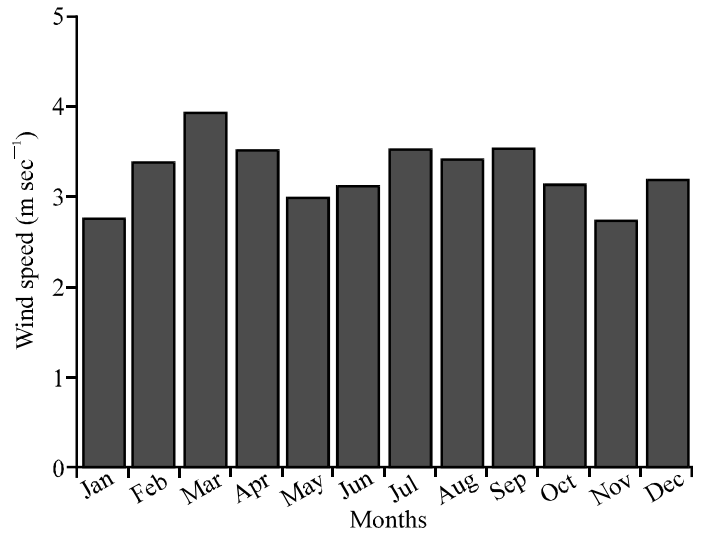

Fig. 1: The monthly mean wind speed in Akure (latitude $7.25^{\circ} \mathrm{N}$ and longitude $5.2^{\circ} \mathrm{E}$ )

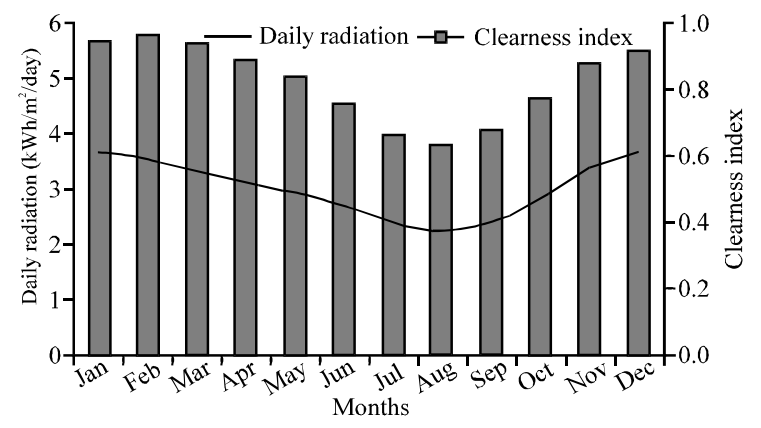

Fig. 2: The monthly daily averaged global solar radiation and clearness in Akure (latitude $7.25^{\circ} \mathrm{N}$ and longitude $5.2^{\circ} \mathrm{E}$ )

Monthly and seasonal variations are observed in the global solar radiation. Like any part of Nigeria, the weather condition in Akure can be classified into two season; dry and wet season. The dry season is from November to March while the wet season starts in April and ends in October. The raining season is characterized by overcast and heavy rain clouds. This give rise to the relatively low global solar radiation observed between the months of May and October compared to the dry season months. The annual averaged daily global solar radiation is $4.933 \mathrm{kWh} / \mathrm{m}^{2} /$ day.

The monthly clearness index which is defined as the fraction of solar radiation at the top of the atmosphere that reaches a particular location on the earth surface varied between 0.37 in the month of August (raining season) and 0.61 in the month of January (in dry season) with an annual average of 0.495 . The clearness index provides information on the level of availability of solar radiation at the surface of the earth as well as changes in atmospheric conditions (Jiang, 2009). The daily averaged global solar radiation for the year 2003 shown in Fig. 3 indicates that the daily global solar radiation in this 


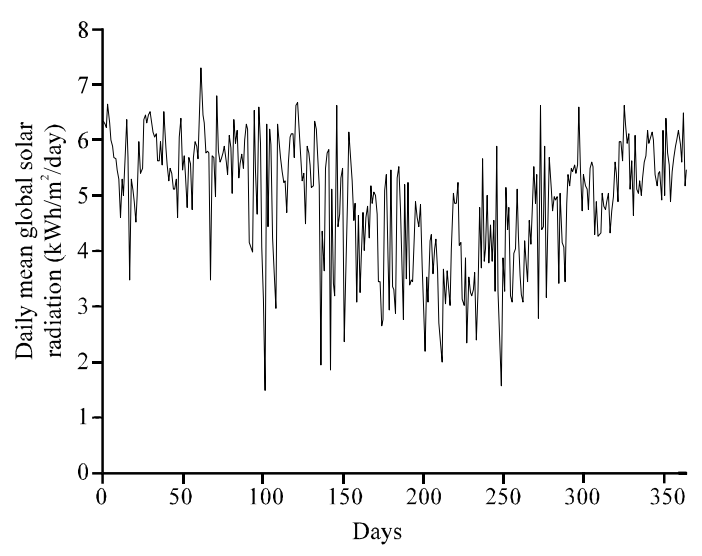

Fig. 3: The 2003 daily averaged global solar radiation and clearness in Akure (latitude $7.25^{\circ} \mathrm{N}$ and longitude $5.2^{\circ} \mathrm{E}$ )

location vary between about $1.5 \mathrm{kWh} / \mathrm{m}^{2} /$ day and about $7.3 \mathrm{kWh} / \mathrm{m}^{2} /$ day with annual average of $4.890 \mathrm{kWh} / \mathrm{m}^{2} /$ day for this year. For sensitivity analysis, seven different annual values of global solar radiation are used and these values are; $3.00,3.50,4.00,4.50,4.93,5.50,6.00$ and $6.50 \mathrm{kWh} / \mathrm{m}^{2} /$ day.

Hybrid system components: The hybrid energy system is designed using National Renewable Energy Laboratory (NREL) software, HOMER (Hybrid Optimization Model for Electric Renewable). HOMER performs three basic calculations; simulation, optimization and sensitivity analysis (Lambert et al., 2006). In the simulation process of HOMER Models, the performance of a particular hybrid system configuration each hour of the year to determine its technical feasibility and life-cycle cost. A feasible system is defined as a hybrid system configuration that is capable of satisfying the require load and meeting other constraints imposed on the system. In the optimization process, many different system configurations are simulated and HOMER search for the system that satisfies the technical and economic constraints at the lowest lifecycle cost.

In sensitivity analysis process, HOMER performs multiple optimizations under a range of input in order to investigate the effects of uncertainty or changes in the model inputs (such as changes in wind speed or diesel price). In this study, hybrid systems with the combination of the following components are investigated; wind energy conversion system (wind turbine), PV module, diesel generator, battery and power converter is (Fig. 4). For each component, HOMER require information about the cost (capital, replacement, operation and maintenance), number (or size) of units to be used, operating hours and lifetime and specific component

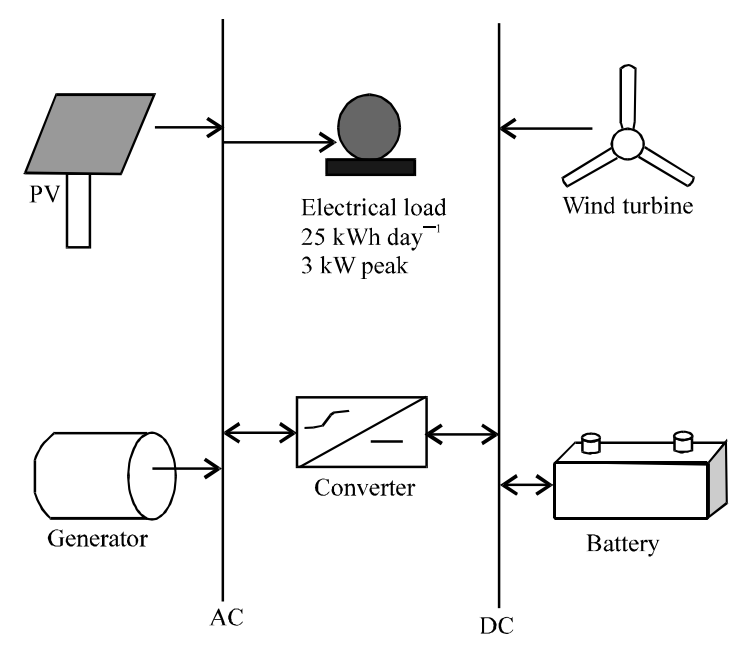

Fig. 4: Schematic diagram of the hybrid system

Table 1: Search space altematives

\begin{tabular}{cccccc}
\hline \multicolumn{1}{c}{$\begin{array}{c}\text { Components } \\
\text { PV array } \\
(\mathrm{kW})\end{array}$} & $\begin{array}{c}\text { WECS } \\
\text { (Quantity) }\end{array}$ & $\begin{array}{c}\text { Generator } \\
(\mathrm{kW})\end{array}$ & $\begin{array}{c}\text { Battery } \\
\text { (Quantity) }\end{array}$ & $\begin{array}{c}\text { Converter } \\
(\mathrm{kW})\end{array}$ \\
\hline Sizes/quantity & 0.0 & 0 & 0.0 & 0 & 2 \\
& 3.0 & 1 & 3.0 & 2 & 4 \\
& 5.0 & & 5.0 & 6 & 6 \\
& 8.0 & & 7.5 & 12 & 8 \\
10.0 & & & 36 & \\
5.0 & 2 & 4 & 5 & 4 \\
\hline
\end{tabular}

properties. Detailed descriptions of each component with the required input data for the HOMER software are shown in Table 1.

Wind energy conversion systems: The performance of a wind turbine is strongly dependent on wind speed as well as its variations. Hence, it is advisable that the rated power of the selected wind turbine should be higher than the peak electrical load. In this study, Bergey Wind Power's BWC Excel-R/48 Model is selected. This model is selected because it is designed for low wind speed regime and can be used as a battery charging system (BWC website). Its rated power is $7.5 \mathrm{~kW}$ and provides $48 \mathrm{~V} \mathrm{dc}$ as output (BWC website). The BWC Excel-R/48 Model is designed to be used with hub height of up to $43 \mathrm{~m}$ high. The cost of $7.5 \mathrm{~kW}$ BWC Excel-R/48 Model is $\$ 26870$ and the cost of the associated tower $(43 \mathrm{~m})$ and towering wiring kits are $\$ 20385$ and $\$ 1850$, respectively (BWC website). The total initial cost is therefore, $\$ 49105$ which gives about $\$ 6550 \mathrm{~kW}^{-1}$. The installation and other initial cost are assumed to be $10 \%$ of the cost of the wind turbine. The operating and maintenance cost is assumed to be $25 \%$ of the annual cost of the wind turbine (system costlifetime). The lifetime of the wind turbine is assumed to be 20 years. In addition, the replacement cost of the 
wind turbine is taken as $\$ 6,000$ in this study. For simulation analysis, provision for using either 0 (no wind turbine) or 1 unit is given.

PV array: The capital and replacement cost of PV array are taken to be $\$ 3,000 \mathrm{~kW}^{-1}$ (Al-Badi, 2011) and $\$ 3,100 \mathrm{~kW}^{-1}$, respectively. The operating and maintenance cost is assumed to be $10 \%$ of the capital cost of a kW of the PV array. Four different PV array sizes are considered which are 0 (no PV array), 3, 5, 8 and $10 \mathrm{~kW}$. The derating factor which compensate for efficiency reduction in the PV performance due to temperature, dust and wiring losses was taken as 0.8 . The lifetime of the PV array is assumed to 20 years and no tracking system is included in the PV system and the ground reflectance is taken as $20 \%$.

Diesel generator: The purpose of the generator is to supplement the power production by the wind turbine and PV arrays especially when the electricity are not met by either them or by batteries (due to state of charge). For this analysis, the generator cost is assumed to be $\$ 450 \mathrm{~kW}^{-1}$ and replacement and operational and maintenance costs are taken to be $\$ 400 \mathrm{~kW}^{-1}$ and $\$ 0.150 \mathrm{~h}^{-1}$ (Khan and Iqbal, 2005). Three different diesel generator sizes are considered for simulation analysis which are 0 (no diesel generator), 3,5 and $7.5 \mathrm{~kW}$. The operating lifetime of the generator is assumed to be $10,000 \mathrm{~h}$. In this study, the diesel generator runs in parallel with the renewable energy conversion systems and requires a certain percentage of the diesel generator time to charge the batteries. A value of $30 \%$ was selected in this analysis as suggested by Givler and Lilienthal (2005). Current diesel price in Nigeria is between $\$ 0.8$ and $\$ 1.0$ $\mathrm{L}^{-1}$. In rural areas and during fuel scarcity, the diesel price may be as high as $\$ 1.4 \mathrm{~L}^{-1}$. Therefore for the sensitivity analysis, diesel price of $\$ 0.6, \$ 1.0$ and $\$ 1.4 \mathrm{~L}^{-1}$ were used.

Battery: The battery is used to meet the electrical load during the non-availability of power from the PV array and wind energy conversion system. In this study, the Surrette 6CS25P models with a nominal capacity of 1156 Ampere-hours (Ah), cell voltage of $6 \mathrm{~V}$, lifetime throughput of $9645 \mathrm{kWh}$, efficiency of $80 \%$ and a minimum state of charge of $40 \%$ are selected. Cost of one battery is taken as $\$ 1250$ with a replacement cost of $\$ 1100$ (Khan and Iqbal, 2005). The operational and maintenance cost is taken as $\$ 11$ year $^{-1}$ (Cotrell, 2003). Five different battery stacks are considered for the simulation analysis. Each stack contain a number of batteries which are 0 (no battery) $2,6,12$ and 36 .

Power converter: A power converter is required to maintain the flow of energy between the ac and dc components of the hybrid energy system and the electrical load. The cost a power converter depends on its size and type (pure sine wave or modified sine wave). The cost $1 \mathrm{~kW}$ converter is assumed to be $\$ 715$ and the replacement cost is taken as $\$ 715$. For simulation analysis, four different sizes of converter $(2,4,6$ and $8 \mathrm{~kW})$ were considered. The lifetime of a unit is taken as 15 years with an efficiency of $90 \%$.

Economic, controls and constraints: The lifetime of the project is taken to be 25 years and the annual real interest rate is taken to be $8.15 \%$. This value represents the average real interest rate in Nigeria between 2006 and 2008. The fixed capital cost is assumed to be $\$ 1500$ and the operations and maintenance costs are taken as $20 \%$ of the fixed capital cost. The maximum annual capacity shortage is taken as $2 \%$ which is within the range of $0.5-5 \%$ suggested by Givler and Lilienthal (2005) and operating reserve as percentage of hourly load is $10 \%$ as recommended by Cotrell (2003). For renewable output, this reserve is 25 and $50 \%$ for solar and wind energy conversion systems, respectively.

HOMER can model two battery dispatch strategies which are loading-following and cycle-charging. Under the load-following strategy, renewable power sources charge the battery but the generators do not. Under the cycle-charging strategy whenever the generators operate, they produce more power than required to serve the load with surplus electricity going to charge the battery bank. In this analysis, cycle-charging was selected because this strategry preserve the lifetime of both the diesel generator and battery and reduces risk of over-dicharging the battery (Cotrell, 2003; Dalton et al., 2008).

System simulation: For each system component, different sizes and number are provided as discussed before and are shown in Table 1. Table 1 shows the search space which is the set of all possible system configurations over which HOMER can search for the optimal system configuration. This search space is made up of 800 different system configurations (product of PV array (5), WECS (2), generator (4), battery (5) and converter (4)).

In addition, the effect of changes in three variables is considered in this study. These variables are wind speed, global solar radiation and diesel price. A total of 192 sensitivity cases (wind speed (8), global solar radiation (8) and diesel price (3)) were tested with each of the system configurations.

\section{RESULTS AND DISCUSSION}

The effect of diesel price on the optimal system configurations are presented in graphical form in Fig. 5-7. 


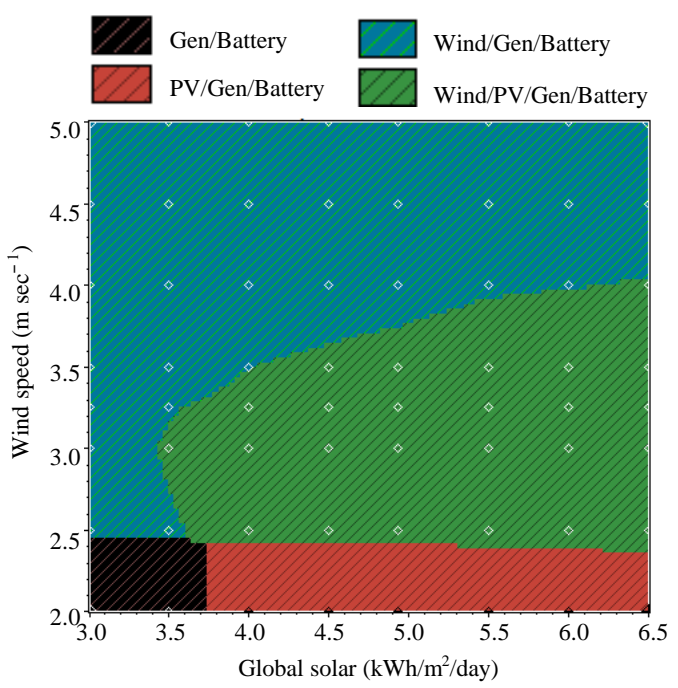

Fig. 5: The optimal system type diagram for diesel price of $\$ 0.6 \mathrm{~L}^{-1}$

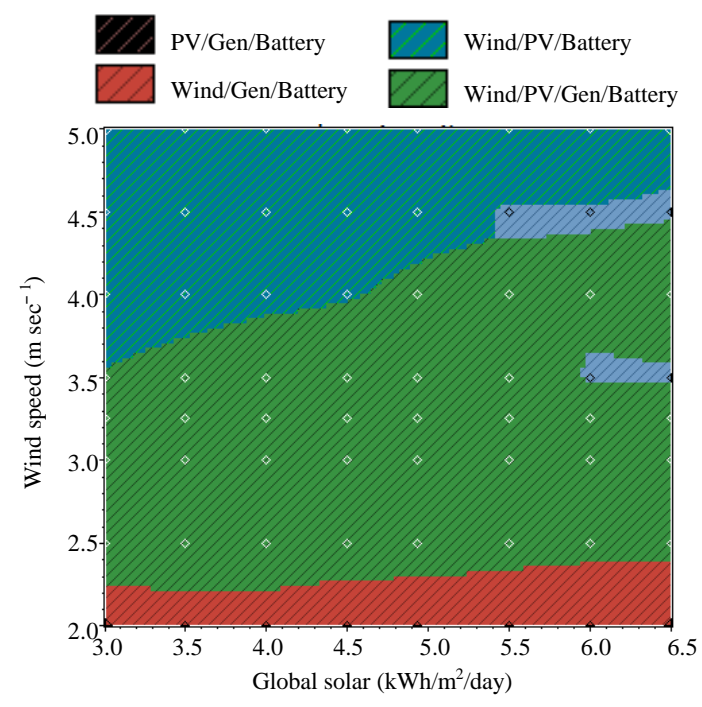

Fig. 6: The optimal system type diagram for diesel price of $\$ 1.0 \mathrm{~L}^{-1}$

An optimal system is defined as a solution for energy system configuration that is able to meet the specified electrical load. Figure 5 and 6 are given in terms of global solar radiation and wind speed. This will enable the results from this study to be applied to other locations within Southern part of Nigeria where the global solar radiation and wind speed are within the range considered in this study. Depending on the diesel price, different energy configuration systems are observed and region covered by each configuration is strongly dependent on the renewable resources. For a diesel price of $\$ 0.6 \mathrm{~L}^{-1}$ (Fig. 5), four distinct configurations are feasible.

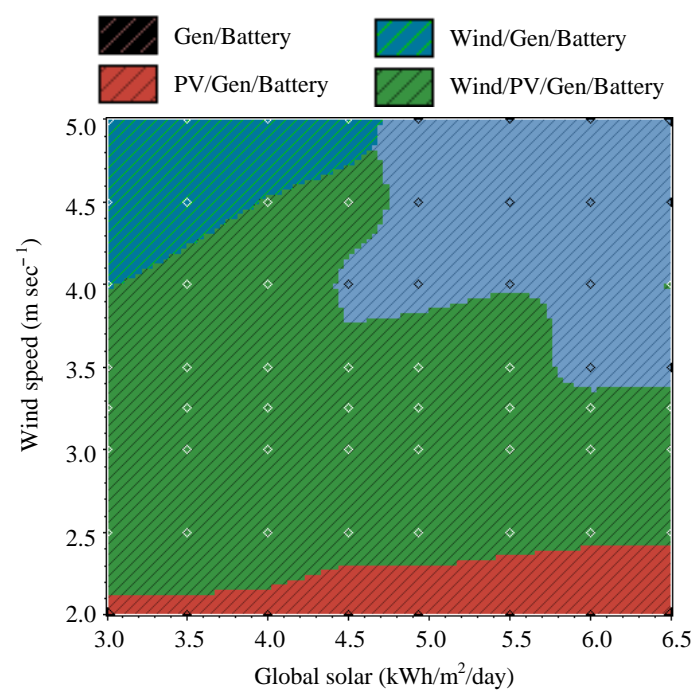

Fig. 7: The optimal system type diagram for diesel price of $\$ 1.4 \mathrm{~L}^{-1}$

These systems are Gen/Battery, PV/Gen/Battery, Wind/Gen/Battery and Wind/PV/Gen/Battery. At low wind speed of $<2.5 \mathrm{~m} \mathrm{sec}^{-1}$ and global solar radition of $<3.8 \mathrm{kWh} / \mathrm{m}^{2} /$ day, Gen/Battey system is applicable. However, when the global solar radiation is greater than $3.8 \mathrm{kWh} / \mathrm{m}^{2} /$ day, a hybrid system which consists of $\mathrm{PV} / \mathrm{Gen} /$ Battery is feasible at low wind speed. At high wind speed $\left(>4.0 \mathrm{~m} \mathrm{sec}^{-1}\right)$, it can be observed from Fig. 7 that irrepsective of the amount of global solar radiation, Wind/Gen/Battery hybrid is best option. The hybrid system with combination of Wind/PV/Gen/Battery is observed to be a feasible option at moderate wind speed and global solar radition of $>3.8 \mathrm{kWh} / \mathrm{m}^{2} /$ day.

With increasing diesel price (Fig. 6-7), the option of using Gen/Battery system is no longer feasible and possibility of using only renewable resources based system and battery is now appear (diesel price of $\$ 1.0 \mathrm{~L}^{-1}$, Fig. 6). The region covered by Wind/PV/Battery system increase as the diesel price increases (diesel price of $\$ 1.4 \mathrm{~L}^{-1}$, Fig. 7). In addition at low wind speed, $\mathrm{PV} / \mathrm{Gen} /$ Battery can be used irrepsective of the diesel price and global solar radiation. It can be further be observed that region where Wind/Gen/Battery and Wind/PV/Gen/Battery are applicable decrease and increase as diesel price increases, respectively. At the location considered in this study which have the annual wind speed of $3.26 \mathrm{~m} \mathrm{sec}^{-1}$ and annual daily averaged global solar radiation of $4.93 \mathrm{kWh} / \mathrm{m}^{2} /$ day, hybrid energy system with combination of Wind/PV/Gen/Battery is optimal system, irrespective of the diesel price. The components and cost analysis of this optimal system in showed in Table 2 as a function of the diesel price. For 
Table 2: Components and cost analysis of this optimal system as a function of the diesel price

\begin{tabular}{|c|c|c|c|c|c|c|c|c|c|c|c|c|}
\hline $\begin{array}{l}\text { Diesel price } \\
\left(\$ \mathrm{~L}^{-1}\right)\end{array}$ & $\begin{array}{l}\text { PV } \\
(\mathrm{kW})\end{array}$ & WECS & $\begin{array}{l}\text { Gen } \\
(\mathrm{kW})\end{array}$ & Battery & $\begin{array}{l}\text { Converter } \\
(\mathrm{kW})\end{array}$ & $\begin{array}{l}\text { Capital } \\
\text { cost }(\$)\end{array}$ & $\begin{array}{c}\text { Operating cost } \\
\left(\text { \$ year }^{-1}\right)\end{array}$ & $\begin{array}{c}\text { Total NPC } \\
\text { (\$) }\end{array}$ & $\begin{array}{c}\mathrm{LCOE} \\
\left(\$ \mathrm{kWh}^{-1}\right)\end{array}$ & $\mathrm{RF}$ & $\begin{array}{l}\text { Diesel } \\
\text { (L) }\end{array}$ & $\begin{array}{c}\text { Genoperating } \\
\text { time (h) }\end{array}$ \\
\hline \multirow[t]{2}{*}{0.60} & 3.0 & 1 & 3.0 & 6 & 2.00 & 29185 & 2502 & 55550 & 0.578 & 0.75 & 1300 & 1787 \\
\hline & & & 3.0 & & 2.00 & 4280 & 7929 & 87847 & 0.913 & 0.00 & 4623 & 8757 \\
\hline \multirow[t]{2}{*}{1.00} & 3.0 & 1 & 3.0 & 6 & 2.00 & 29185 & 3111 & 61978 & 0.644 & 0.75 & 1327 & 1897 \\
\hline & & & 3.0 & & 2.00 & 4280 & 9778 & 107337 & 1.116 & 0.00 & 4623 & 8757 \\
\hline \multirow[t]{2}{*}{1.40} & 5.0 & 1 & 3.0 & 12 & 4.00 & 44915 & 1962 & 65590 & 0.682 & 0.92 & 395 & 458 \\
\hline & & & 3.0 & & 2.00 & 4280 & 11628 & 126827 & 1.319 & 0.00 & 4623 & 8757 \\
\hline
\end{tabular}

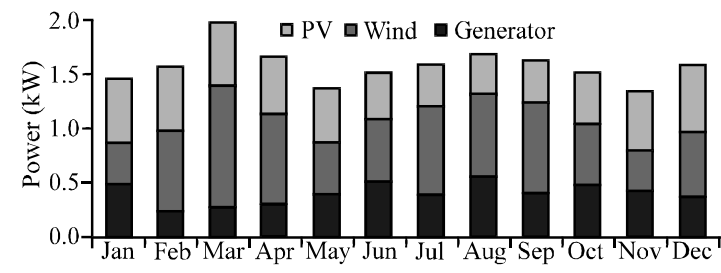

Fig. 8: Monthly average electricity production by the hybrid system for diesel price of $\$ 1.0 \mathrm{~L}^{-1}$

diesel price of $\$ 0.6$ and $\$ 1.0 \mathrm{~L}^{-1}$, the hybrid system is made up of $3 \mathrm{~kW} \mathrm{PV,} 1$ BWE Excel-R wind turbine $(7.5 \mathrm{~kW}), 3 \mathrm{~kW}$ generator, 6 S6CS25P battery and $2 \mathrm{~kW}$ converter. However, at diesel price of $\$ 1.4 \mathrm{~L}^{-1}$, the PV capacity increased to $5 \mathrm{~kW}$ and as expected, the require number of battery and converter are now $12 \mathrm{~S} 6 \mathrm{CS} 25 \mathrm{P}$ and $4 \mathrm{~kW}$, respectively. Also, Table 2 shows that the cost analysis of using only generator based energy system (without battery) to supply the required electrical load. For the hybrid system, the unit cost of electricity are $\$ 0.578,0.644$ and $0.682 \mathrm{kWh}^{-1}$ for diesel price of $\$ 0.6,1.0$ and $1.4 \mathrm{~L}^{-1}$, respectively. For the generator based system, levelised cost of electricity is observed to vary between $\$ 0.913 \mathrm{kWh}^{-1}$ (for diesel price of $\$ 0.6 \mathrm{~L}^{-1}$ ) and $\$ 1.319 \mathrm{kWh}^{-1}$ when the diesel is $\$ 1.4 \mathrm{~L}^{-1}$.

Notwithstanding of the high intial capital cost of the hybrid system, it can be seen that its total Net Present Cost (NPC) is lower than generator based system. This is because of the low operating cost of the renewable energy conversion systems when compared with the generator system. It can be further observed that the renewable energy systems production penetration fraction $(\mathrm{RF})$ incerase with increasing diesel price. The monthly average electricity produced by each component of the hybrid system is shown in Fig. 8 for the diesel price of $\$ 1.0$. Figure 8 shows that electricity produced by each component vary from one to another and from month to month. This is due to variation in monthly wind speed and global solar radiation in the location considered in this study. The simulation analysis shows that the total electricity production $\left(13,755 \mathrm{kWh}\right.$ year $\left.^{-1}\right)$ meet the electrical load $\left(9,125 \mathrm{kWh}_{\text {year }}^{-1}\right)$ by the combination of $32 \% \mathrm{PV}, 43 \%$ wind and rest of $25 \%$ by generator with excess electricity of $2838 \mathrm{kWh}_{\text {year }}{ }^{-1}$.

\section{CONCLUSION}

The feasibility of using hybrid energy system in rural communities in Akure is examined using HOMER in this study. The results presented in this study show that the cost of generating electricity using hybrid energy system is significantly cheaper than using only generator based energy system. Although, the initial capital cost of the hybrid system is higher than the generator system, its low operating and maintenance cost make it more suitable for rural areas where accessibility to diesel to power the generator may be difficult. In addition, using the sensitivity analysis results, the findings of this study can be applied to some other locations within Ondo state and surrounding states that have similar wind speed regime and global solar radiation to the site considered in this study. By using hybrid energy system, access rate to electricity in the rural area of the state where national electricity grid extension could be difficult or expensive to achieve can be increased. In addition, some of the advantages of the hybrid energy system over generator based energy (with no storage system) include constant and reliable electricity supply; operating period of the generator can be reduced and hence, less diesel consumption which can result in lower greenhouse gases emission. The reliable supply of electricity through the hybrid system can improve the standard of living and economic activities of the rural habitants.

\section{REFERENCES}

Adaramola, M.S. and O.M.Oyewola, 2011. Evaluating the performance of wind turbines in selected locations in Oyo state Nigeria. Renewable Energy, 36: 3297-3304.

Adeoti, O., B.A. Oyewole and T.D. Adegboyega, 2001. Solar photovoltaic-based home electrification system for rural development in Nigeria: Domestic load assessment. Renewable Energy, 36: 155-161.

Ajao, K.R., O.A. Oladosu and O.T. Popoola, 2011. Using homer power optimization software for cost benefit analysis of Hybrid-solar power generation relative to utility cost in Nigeria. Int. J. Res. Rev. Appl. Sci., 7: 96-102.

Al-Badi, A.H., 2011. Hybrid (solar and wind) energy system for Al hallaniyat island electrification. Int. J. Sustainable Energy, 30: 212-222. 
Cotrell, J., 2003. Modeling the feasibility of using fuel cells and hydrogen internal combustion engines in remote renewable energy systems. Technical Report. NREL/TP-500-34648, 2003.

Dalton, G.J., D.A. Lockington and T.E. Baldock, 2008. Feasibility analysis of stand-alone renewable energy options for a large hotel. Renewable Energy, 33: $1475-1490$.

Givler, T. and P. Lilienthal, 2005. Using homer software, NREL's micropower optimization model, to explore the role of gen-sets in small solar power systems case study: Sri Lanka. Technical Report NREL/TP-71036774 May 2005. National Renewable Energy Laboratory, Colorado.
Jiang, Y., 2009. Correlation for diffuse radiation from global solar radiation and sunshine data at Beijing China. J. Energy Eng., 135: 107-111.

Khan, M.J. and M.T. Iqbal, 2005. Pre-feasibility study of stand-alone hybrid energy systems for applications in Newfoundland. Renew. Energy, 30: 835-854.

Lambert, T., P. Gilman and P. Lilienthal, 2006. Micropower System Modeling with Homer. In: Integration of Alternative Sources of Energy, Farret, F.A. and M.G. Simoes (Eds.)., John Wiley and Sons Inc., Hoboken, New Jersey, USA., pp: 379-416. 